\title{
䕀案隹 誌
}

第六十卷第一號

昭和十五年一月發行

報文

\section{Dibenzochinolizin 類の合成研究}

菅澤：重 苶

東大藥學科数窒 (昭和 15 年 1 月 6 日受理)

窒素を Verzweigungsatom として有する天産化合物はその數尠なかららす，其の中には Chinuclidin-核を有する Chinin-族アルカロイドの如く極めて重要をるもの存するもかかる窒素を 有する化合物の大多數は下式（I）飞示す Chinolizin（刃は Pyridocoline）の誘導體なり。例 之 Berberin-族化合物, Matrin, I upinin, Spartein 等の如し. 而して此等諸種化合物中最も 古くょり知らるる Berberin-族化合物は下式 (II)-(VII) 飞示す理論上可能なる六種の Dibenzochinolizin 類中 (II) 郎ち 2,3；7,8-Dibenzochinolizin-誘導體に屬し其構造住合成的飞を 既に確證されたるすのなり。然るに殘る 5 種の化合物（III)-(VII) はそれ等自身叉はそれ

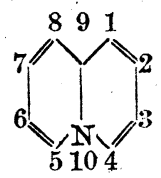

I

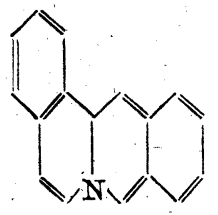

II

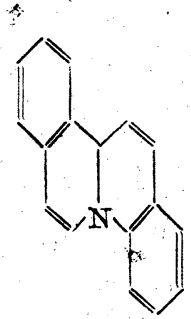

III

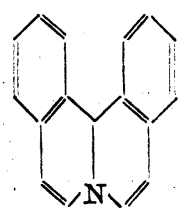

IV

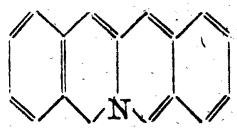

V

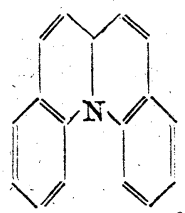

VI

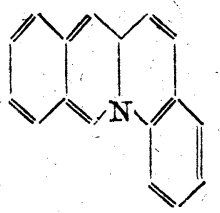

VII 
らの誘導體も天然に破見されたるものなく又合成的にも確實に記載され、たるものなし.'伥つて 余は此等化合物の合成を行ひ交獻上の缺を補ひ㴊せてその生理作用を驗せんとし教室是の協力 を得て本研究に着手したり。

抬本研究費用は帝國學士院の援助金を以て之を支辨したり。謹みて感謝す。

\section{Dibenzochinolizin 類の合成砫究（第一報）}

\section{$4^{\prime}, 5^{\prime}, 4^{\prime \prime}, 5^{\prime \prime}$-Tetramethoxy-1,2,5,6-tetrahydro- $\left[1^{\prime}, 2^{\prime}: 3,4\right.$; \\ $1^{\prime \prime}, 2^{\prime \prime}: 7,8$-dibenzo-chinolizin] $の$ 合成}

掛見 喜 一 郎

東大藥學科敎室 (昭和 15 年 1 月 6 日受理)

本骨骼を有する化合物に就きて文㱆を按するるて記載例極めて抄く僅かに管澤, 吉川网比)は Homolaudanosolin の鹽類 (VI) C Chloranil を用ひて脫水素化し $4^{\prime}, 5^{\prime}, 4^{\prime \prime}, 5^{\prime \prime}$-Tetraoxy-10methyl-1,2,5,6-tetrahydro-[1',2 : 3,$4 ; 1^{\prime \prime}, 2^{\prime \prime}: 7,8-$ dibenzochinolizin $]$ 鹽 (VII).なりと暗示せ り.されど當時得られたる (VII) 乙思しき物質の量極めて少く, 其 O-Methyl 化誘導體も亦 滿足すべき分析結果を與へす且其構造て對する積極的の證明も行はれ居らず. 其棈造を合成に

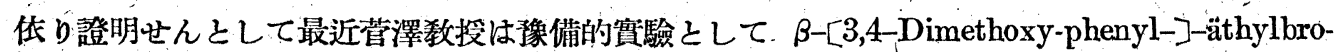
mid と 6,7-Äthylendioxychinolin ょり下式に示す徑路にて $4^{\prime \prime}, 5^{\prime \prime}$-Dimethoxy-4',5'-äthylendioxy-5,6-dihydro-9,10-dehydro- $\left[1^{\prime}, 2^{\prime}: 3,4 ; 1^{\prime \prime}, 2^{\prime \prime}: 7,8\right.$-dibenzochinolizin $]$ 㯺 (VIII) の命 成娍功したり².

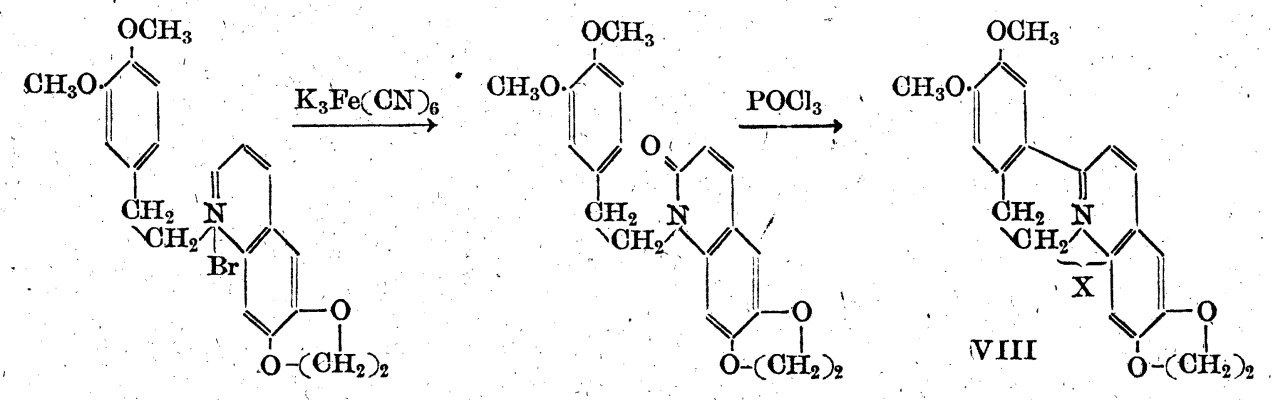

1) 管澤, 吉川：本誌 54, 305 [昭 9]. 2) 菅澤：本誌 57, 1028 [昭 12]. 